\title{
ЗАУМЬ В ЗАГОВОРНОЙ ТРАДИЦИИ КОМИ: В ПОИСКАХ ИСТОКОВ
}

\author{
Анатолий Панюков \\ apankomisc@mail.ru
}

Аннотация: Чтобы дать общее представление о специфике проблематики, обозначенной в заглавии статьи, автор предлагает рассмотреть два конкретных примера из заговорной традиции коми. В аналитической части статьи выдвигаются две авторские гипотезы. Гипотеза первая: языковые трансформы, верифицируемые как заумь, могут возникать в результате компрессии грамматически правильного текста-источника (предтекста, прототекста) в ритмическую матрицу заговорного акта. Под ритмической матрицей понимается сложноорганизованная, фиксированная структура ритмических подсистем: звуко-ритмической, ритмомелодической, метрико-ритмической и других размерностей. Гипотеза вторая: компрессия прототекста в заговорный текст может иметь нелинейный характер и являться результатом особой стратегии передачи заговорного знания от учителя ученику. В силу определённых психофизиологических установок и ограничений ученик не запоминает сам заговорный текст, а воспроизводит более глубинные уровни магико-ритуального перформатива, связанные с ритмической матрицей. И уже в эту матрицу, воспроизведённую его сознанием, встраивается новый вербальный ряд, собранный из компонентов текста-источника, зафиксированных кратковременной памятью обучаемого.

Ключевые слова: фольклор, коми-зыряне, заговорная заумь, заимствования, ритм, структура, ритмическая матрица 


\section{Введение в проблематику}

Онтологическая двуприродность заговоров (особый фольклорный жанр и особая разновидность ритуала) позволяет совмещать в едином феномене ряд противоположных или даже взаимоисключающих явлений (Топоров 1993: 3). Одним из таких парадоксальных свойств коми заговорной традиции нилкыв видзел можно назвать взаимопроникновение признаков устойчивости и изменчивости. С одной стороны, в традиции доминирует магическое отношение к заговорному слову, что как бы не допускает никаких вариаций при использовании и передаче «знаний». С другой - перед нами чрезвычайно текучая и склонная к инновациям традиция. Обилие русскоязычных заимствований, характерное для многих пластов фольклора коми, в контексте заговорной поэзии объясняется универсальными для традиционных культур представлениями об особой силе «чужой» магии. Однако это противопоставление не столь тривиально, и даже на уровне локальных или микролокальных «узусов" может иметь разную знаковость. Так, например, Алексей Сидоров отмечал, что локчимские коми (средняя Вычегда) считали коми заговоры сильнее русских (Сидоров 1997: 102). Кроме того, поскольку в силу сложившихся культурноисторических реалий именно русский язык противопоставляется обыденному коми языку, он легко включается в сферу заговорного «словотворчества» («иной» язык как магический). Помимо непосредственного влияния севернорусской заговорной традиции, представлявшей сложноорганизованный континуум фольклорной и церковно-христианской, письменной культуры (Топорков 2008: 13), в магический «оборот» вводился и непосредственный опыт церковно-приходской жизни и обиходные знания русского языка и русской культуры. Все эти иноязычные инновации, попадая в другую фольклорную реальность, могли обретать новую знаковость и прагматику.

Глубина такого межкультурного и межъязыкового синтеза становится очевидной, как только мы предпринимаем попытку отделить автохтонные, рождённые коми фольклорным сознанием тексты от «чистых» заговорных заимствований, в ходе ретрансляции потерявших семантическую ясность. В общей картине бытования заговорной традиции можно выделить 
целый ряд «самоподобных» текстологических «ниш», заполненных явными инновациями: заимствованными русскими заговорами (рукописными и устными), «народными» и каноническими молитвами и формулами разной степени идентичности первоисточникам, а также новыми магическими текстами, возникающими на основе синтеза концептуальных возможностей традиции. Однако при всех этих нововведениях традиция сохраняет свою структурную идентичность (Панюков 2009: 187-189) и в таком качестве может быть включена в общую проблематику межэтнических взаимодействий и взаимопроникновений в области заговорно-заклинательного фрольклора разных народов (Самошкин 1975; Болонев \& Мельников 1997: 271-272; Левкиевская 1999: 279-282; Никонова 2000: 104; Кляус 2004; Завьялова 2006; Панина 2014: 171-179).

Концептуальное единство заговорной традиции требует определённых корректив и для заявленной темы. Несомненно, фрольклорная заумь - явление универсальное и многогранное и по своему происхождению («тайные» языки, изменённые фрормы сознания, детское словотворчество, иноязычные заимствования и т. д.), и по своим фрункциям (обслуживающим широкий спектр ритуально-магических и игровых форм коммуникации с «иным» миром), и по степени удалённости от естественного языка (от фонетической - «чистая бессмыслица», когда звуки не складываются в морфемы, до супрасинтаксической - когда при формальной, грамматической правильности языковых конструкций остаётся принципиально неясным, о чём идёт речь (Janecek 1996).

Общепризнанная сегодня взаимосвязь всех видов зауми с родным языком носителя (любая заумь является актуализацией языковой и культурной доминанты) предполагает поиск заложенных в нём смыслов на периферии нормативного языка, в области звукосемантических ассоциаций, актуальных для исполнителя / слушателя (Шляхова 2006). Субъективный фрактор, доминирование эмоционально-интуитивного начала в восприятии зауми определяет вероятностный характер текстологических исследований. Тем не менее, это не лишает нас возможности говорить об определённых правилах формальносмысловой организации заумных текстов (Панюков 2010). Доминирующий сегодня интерпретационный подход к поэтической зауми предполагает поиск семантики текста через смысловой 
«перевод» выявляемых подтекстов: внутриязыковых, иноязычных, инокультурных, связанных с иными типами знаков, как правило, иконических или индексальных (звукоподражание, извлечение «внутренней языковой формы», транспонирование математического, аудиального или визуального в вербальное и пр.), а порой и символических (шифр, модельные грамматические или синтаксические абстракции). Наиболее радикальными аналитиками высказывалась позиция о принципиальной семантической открытости - декодируемости зауми (Давыдов 2007: 66).

Применительно к заговорной традиции коми пафос интерпретационных возможностей сдерживает, прежде всего, неопределённость границ самого языкового модуса, определяемого как заумь. Если подходить к нему с позиций дистанционирования от доминантной языковой структуры, то практически в каждом заговорном тексте обнаруживаются языковые «сдвиги», которые можно квалифицировать как заумь. Прежде всего, это связано с обилием русскоязычных компонентов, которые в моноязыковой среде обретают иную мотивировку и включаются не только в репертуар, но и в поэтический арсенал традиции (в виде текстостроительных элементов с неопределённой семантикой - квазиморфем, квазислов, квазисинтаксических структур различной степени сложности). Далее, семантическую неопределённость заговорным текстам придаёт и «внутренняя» специфика жанра. В расширенном понимании нилкьв обозначает совокупность способов словесно-магического воздействия на природу, которые отличаются и в способах организации вербального текста (Уляшев 1999). Специфическую «эллиптичность», требующую контекстуальных знаний, придаёт заговорам-нилкыв номинативный принцип текстосложения, концептуально выраженный и соотносимый с буквальным значением этого термина (нил 'имя' + кыь 'слово; язык'), когда нилкыв представляет собой определённый набор ключевых слов или вообще состоит из одного слова (У ляшев 1999). Но нельзя здесь обойти и онтологическую двуприродность заговорной стихии, в соответствие с которой в любом заговорном тексте обнаруживаются семантические «пустоты», восполняемые невербальными смыслами. Вопрос о том, что происходит с этими «пустотами» при попадании в иноязыковую и инокультурную среду, достоин отдельного обоснования. Таким образом, при самой постановке темы «Заумь 
в заговорной традиции коми» возникает несколько проблемных вопросов, связанных как с происхождением отдельных явлений «зауми», так и их бытованием. Чтобы обозначить суть поднимаемой проблематики, ниже мы рассмотрим два заговорных текста, характеризующих состояние традиции.

\section{Заумь в автохтонном заговорном тексте}

Для начала обратимся к заговорному тексту, связанному с «культурообразующей» для коми-зырян сферой охотничьей магии (см., например, статью Ирины Ильиной и Олега Уляшева в настоящем сборнике). Он представляет собой достаточно типичную для традиции контаминацию коми и русских компонентов, но при этом его автохтонность сложно подвергнуть сомнению. Это заговор на клестов, используемый в подростковой промысловой практике (произносится при установке силков; об этой традиции см. Панюков 2014): Кальць кальцьь сюр-ньььр сюрньыр, сер борд сер борд нал белогом дал садись ${ }^{1}$. В рукописной записи заговор дан в линейном виде, однако, исходя из очевидной ритмики, стоит преобразовать его в строчный вид:

Кальць, кальиьь,

Сюр-нььь, сюр-ньыр,

Сер борд, сер борд,

Нал белогол дал,

Caдucb!

Кроме того, что финальная часть сконструирована из русских (нал, дал, садись) и коми (белог) компонентов и, как минимум, «заумна» на синтаксическом уровне, все коми слова здесь по каким-то причинам деформированы. Поэтому, прежде чем дать хотя бы приблизительный перевод заговора, обозначим наиболее явные искажения.

\section{Кальиьс кальиь:}

< кальсы 'клёст'; русская фонема u в коми языке на стыке двух слогов передается через дифртонг $m c$, поэтому окказиональ-

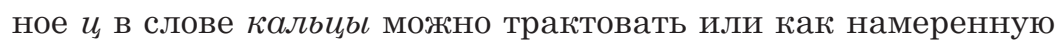
ориентацию на «иноязычность» (русскоязычность) заговора, или 
как вариант фиксации собирателем явного артикуляционного сдвига согласной $c$. Такое «озвончение» согласной могло возникнуть в результате перехода на артикуляционно усиленный речевой регистр, который соответствует особым образом произносимому заклинанию или закличке (с напевом);

+ (?) звукоподражательный бином: кальиы-кальиы < кальскыны 'лязгать, звякать, стучать железом о железо'; кульскальс звукоподр. 'звякнуть (напр. металлом об металл)'; во время переклички клесты издают резкие, высокие металлические звуки, похожие на "глипп-глипп», или "кле-кле» (откуда, вероятно, и название клёст).

\section{Сюр-нььц, сюр-нььц:}

$<$ ныыр < ныр 'клюв, нос' (ассимиляция по мягкости);

сюр (1) < сюр 'рог; рожок; носик, рыльце'; возможный перевод: «рожкообразный нос» (?);

+ сюр (2) 'чёрствый, твёрдый, сухой' (сюрлыны 'зачерстветь, затвердеть, засохнуть (о хлебе)';

+ сюр (3) 'упитанный, здоровый' (сюр чань койд 'упитанный, здоровый’ букв. 'как упитанный жеребец’ (ССКЗД: 360). Возможный перевод: «крепкоклювый», «толстоклювый» (?);

+ сюр (4) < сюр 'попадись' > императив сюр ныр 'попадись, коснись клювом';

+ сюр $(5)<$ фоносемантическое сближение сюр - сер (сюр (ныр) // сер (борд)); может быть сопоставлено с ономатопоэтическими сюр-сяр 'загреметь, загрохотать'; сюр-сярлунны 'рассыпаться'; 'быть рассыпчатым (о картофеле)' (ВВД: 195).

\section{Сер борд, сер борд:}

< сер борд < сера борд ‘пёстрое крыло', сера борда 'пестрокрылый';

+ сюр (ныр) // сер (борд) < фоносемантическое сближение;

\section{Нали белогол дал:}

< белӧг < велӧг 'привада' (озвончение как результат перехода на артикуляционно усиленный речевой регистр);

белогол < 'с привадой-угощением' 
нали: < к нам <на приваду> (?) // на нашу <приваду> (?)

+ фоносмысловое сближение рус. нал / коми менал велӧгӧ 'на мою приваду'.

Эту ассоциацию можно подкрепить другим, тоже верхневычегодским вариантом формулы: менал бэлэге садись, чужей бэлэге не садись 'на мою приваду садись, на чужую приваду не садись'. В других локальных традициях эта фрормула моноязычна, например: Й̈̈з вӧлӧга эн ветлы, ас вӧлӧга лок ' $\mathrm{K}$ чужой приваде (угощению) не летай, к своей приваде лети' (см. Панюков 2014: 147-148).

Белогом дам > 'дам <угощенье>' (?)

+ внутренняя рифмма нал - дам

+ финальная формула-триада, сопоставимая с троектратными заговорно-заклинательными закрепками (троекратное заманивание, троекратное сплёвывание и т. п.); фринальные формулы-триады характерны и для детского фольклора коми (например, считалок);

\section{Caдucb:}

в данном варианте русский глагол может быть рассмотрен как «магически усиленный» аналог коми императива пукси / пуксыь 'садись'. В качестве параллели можно привести ещё один «контаминированный» детский заговор с комиязычной заклинательной формулой «садись на ловушку, пни по кляпцу»:

Кай, кай, прилетай.

Пезин вылӧ пукси,

Калябечсӧ чужйи.
Птичка, птичка прилетай.

Садись на капкан,

Пни по кляпцу.

(Панюков 2014: 154).

Обобщая рассмотренные ассоциативные смыслы, содержание этого заговора можно выразить так: «Клёст, клёст / «клё-клё» говорящий /, крепкий клюв / рожконосый (?) / попадись, коснись носом /, пёстрые крылья (пестрокрылый), [лети] к нам, на нашу приваду, [на наше угощенье] садись!».

Далее, учитывая выявленные сдвиги (фонетические, морфологические, лексические, синтаксические), можно попытаться реконструировать лексико-синтаксический облик текста, соответствующий языковой норме (хотя бы применительно 
к комиязычной части, поскольку «русскоязычную» деформированную часть сложно привести к однозначному варианту). Этому реконструированному фрагменту заговора соответствует грамматически точный перевод:
Кальсы, кальсьи,
Клёст, клёст,
Сюра ныра, сюра ныра,
С крепким носом,
Сера борда, сера борда.
с крепким носом,
С пёстрыми крыльями,
с пёстрыми крыльями.

Оговоримся, что в силу отмеченных нами «разночтений» фррагмента сюр-ньыр реконструкция может быть несколько иной (сюр-ныььр < сюр-ныр < сюрӧд ныртӧ 'попадись, коснись клювом'), однако для наших дальнейших размышлений это непринципиально. Важно, что «нормальный», лексико-синтаксически правильный текст здесь может быть определён как «предтекст», из которого в результате определённых трансформаций и создаётся семантически размытый, «заумный» вариант. Для того чтобы создать заумный текст заговора, в языковом сознании должен возникнуть «предтекст»-норма, который трансформируется «переводится» на «иной», «магический» язык. Помимо соответствия лексико-синтаксической «норме» «предтекст» должен обладать и просодической «нормой» (здесь и далее - ударные гласные обозначены строчными буквами):

$$
\begin{array}{llll}
\text { КаЛьСЫ, КаЛьСЫ, } & \mathbf{v}-\mathbf{v}- & \\
\text { СюРА-НыРА, СюРА-НыРА, } & \mathbf{v}-\mathbf{v}-\mid \mathbf{v}-\mathbf{v}- \\
\text { СеРА БоРДА, СеРА БоРДА. } & \mathbf{v}-\mathbf{v}-\mid \mathbf{v}-\mathbf{v}-
\end{array}
$$

Поскольку рассматриваемый микротекст составлен из двусложных лексем, ритмическая структура слов задаёт «чистый» двусложный размер - хорей. Принцип удвоения слов, вероятно, должен быть заложен уже в «предтексте», и, в соответствие с инципитом, весь текст может быть записан как «чистый» двустопный хорей.

Для того чтобы более наглядно представить расхождение в формальной организации анализируемого заговора и его «предтекста»-нормы, повторим ту же процедуру: 


$\begin{array}{ll}\text { КаЛЬЦ(Ы), КаЛЬЦ(Ы), } & \mathbf{v}(-) \mathbf{v}(-) \\ \text { СюР-НьыР, СюР-НьыР, } & \mathbf{v} \mathbf{v} \mathbf{v} \\ \text { СеР БоРД, СеР БоРД, } & \mathbf{v} \mathbf{v} \mathbf{v} \\ \text { НаМ БеЛОГОМ ДаМ } & \mathbf{v} \mathbf{v}-\mathbf{v} \\ \text { (?) СаДИСЬ // САДиСЬ } & \mathbf{v}-/ /-\mathbf{v}\end{array}$

Очевидно, что перед нами совершенно иная ритмическая структура, почти целиком заполненая спондеями. В соответствие с общей тенденцией к редукции («спондеизации»), можно допустить, что конечная согласная «ы» в слове кальцы тоже должна быть редуцирована, т. е. может быть рассмотрена как огласовка согласного «ц» $[\mathrm{ts}]:$ если бы «ц» был конечным согласным, он бы произносился с такой же редуцированной гласной. Таким образом, из общей метрики «выбиваются» лексемы белогол и садись; соответственно, они приобретают и особую смысловую маркированность. Произношение лексемы садись может быть двояким: в соответствие с нормами русского языка здесь должен быть ямб (САДиСЬ); в соответствие с общей ритмической организацией (и проекцией на коми аналог пукси 'садись') следует ожидать здесь хорей (СаДИСЬ). Оба варианта вносят свою специфику в общую ритмомелодику заговора, но отсутствие звуковой записи заговора не позволяет делать каких-либо предпочтений. Как бы то ни было, перед нами почти «чистая» спондеическая структура. И, если в поэзии ритмическая напряжённость спондеев адекватна «императивным» темам барабанного боя, воинской команды или марша (о спондеике как особом принципе стихосложения см. Андреев 2000), то здесь эта напряжённость явно проявляет жанровую специфику. То есть данный заговор представляет собой особый речевой жанр - заклинание, направленное на принуждение адресата к определённому действию, выраженному финальным императивом «садись в ловушку».

Далее, «предтекст»-норма и текст могут быть противопоставлены как «полногласный» (хореистический) и «неполногласный» - вибрантный (спондеический) ритмические версии: в заговорном тексте безударные гласные коми слов заменены вибрантами (СюР-НьыР , СеР БоРД); здесь же явное нагнетание концевых сонорных (НаМ БеЛОГОМ ДаМ); здесь же озвончение «с» > «ц» (кальсы > кальцы). Вся это придаёт заговору особую звукоритмическую «напряжённость». 


\section{Предварительные выводы}

Структура рассмотренного заговора представляет собой ритмическую (звукоритмическую, метрико-ритмическую) матрицу (многомерную, жёстко фриксированную структурную основу), которая соответствует прагматике и семантике заговора («заклинание»). «Неправильный» (= заумный) текст возникает в результате компрессии «предтекста»-нормы в более соответствующую заговору-заклинанию ритмическую матрицу. Все уровни «неправильностей» данного текста взаимообусловлены и, по всей видимости, вторичны по отношению к ритмической структуре заговора. Таким образом, именно ритм как динамический фрактор текстообразования порождает и организует заговорный текст. ${ }^{2}$

На основе предварительных выводов сформулируем соответствующую гипотезу: языковые трансформы, верифицируемые как заумь, могут возникать в результате компрессии грамматически правильного текста-источника (предтекста, прототекста) в ритмическую матрицу заговорного акта. Под ритмической матрицей понимается сложноорганизованная, фриксированная структура ритмических подсистем: метрико-ритмической, звукоритмической, ритмомелодической и других размерностей. В контексте синергетической концепции языкового текста наше определение ритмической матрицы может быть опосредовано синергетическим представлением о метроритмической матрице, понимаемой как ритм самой структуры целого. Метроритмическая матрица встроена в текст и неосознанно воспроизводится человеком (Манаков \& Москальчук 1999: 58-62).

\section{Заумь в заимствованном заговорном тексте}

Теперь попытаемся применить наши аналитические выкладки к другому заговорному тексту, «чужеродность», т. е. русскоязычность которого столь же очевидна, как и автохтонность предыдущего. 
Этот заговор связан с традиционной магико-медицинской практикой, однако в нашем распоряжении есть только письменная фиксация заговорного «акта».

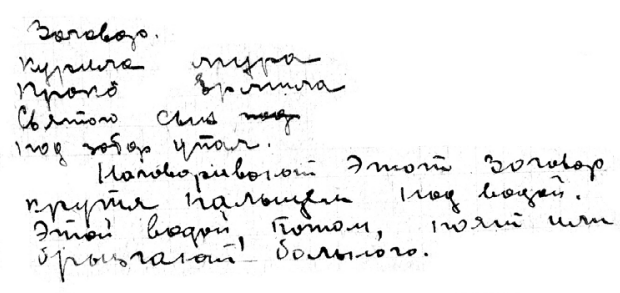

Курила мура

Прокӧ Ерлила

Сеятого сын

Под забор упал.

Наговаривают этот

заговор крутя пальцел под водой. Этой водой, потол, поят или брызгают больного ${ }^{3}$.

По архивным данным, заговор был записан студенткой Сыктывкарского Педтехникума в июне 1935 г. во время фольклорной практики. К сожалению, собиратель не зафиксировал паспортных данных, но, если исходить из других записей, этот текст мог быть записан в Гривенском с/с Койгородского района Республики Коми. Как бы то ни было, по языковым особенностям текста можно утверждать, что, несмотря на явную русскоязычность, он был записан от комиязычного исполнителя.

Вначале обратим внимание на акциональный уровень. Судя по действиям, сопровождающим заговаривание, перед нами вариант распространённого в коми традиции магического лечения от сглаза - волидз, в котором опрыскивание и отпаивание заговорённой водой могут взаимодополнять друг друга. Например, в подробно описанных А. С. Сидоровым способах лечения волидз, после опрыскивания заговорённой водой, больному давали испить эту воду, «чтобы болезнь не бросилась во внутренности»; кроме того, могли ещё устраивать «душ» из той же заговорённой воды: для этого на грядках печи (сёр) ставили решето, и через него обливали сидящего под решетом больного (Сидоров 1997: 159). Однако в данном случае мы имеем дело с весьма упрощённым вариантом приготовления заговорённой воды, не требующим специальных условий или атрибутов (жёсткая связь с определённым временем или местом, перекрещивание воды ножом, использование камней, пропускание воды через камни или дверную ручку и т. п.). Вероятно, перед нами окказионально возникший вариант «мобильного», т. е. легко 
воспроизводимого в любых условиях способа лечения, аналогов которому нам пока не удалось найти ни в каких других традициях. Тем не менее, именно такой, нехарактерный для заговорной традиции вариант имеет своего рода «примарную мотивированность»-это водоворот. В культуре многих народов воде, взятой из водоворота, приписываются особые магические свойства (о славянских традициях см. Виноградова 2002: 35). У коми-зырян магическими свойствами наделялся и песок, взятый из водоворота: «Песок, взятый из водоворота реки, обладает особым свойством изводить в жилых помещениях клопов. Поверье основано, по всей вероятности, на том, что в водовороте песок вертится, совершает круги и этим приобретает магические свойства» (Сидоров 1997: 211).

Исходя из того, что перед нами русскоязычный текст, деформировавшийся в силу попадания в чужеродную языковую среду, «прочитаем» его в русской просодике:
КУРИЛА МуРА
ПРоКӦ ЕРМИЛА
СВЯТоГО СъН
ПОД ЗАБоР УПаЛ.

Текст состоит из двух отличающихся и по фрормальным и по смысловым признакам частей (микротекстов).

Микротекст 1 - явно деформированный фрагмент русскоязычного текста с комиязычным компонентом ПРоКӦ, который здесь, вероятно, является местной формой имени Прокопий. Соответственно, строка Прокӧ Ерлила может быть интерпретирована или как местная форма полного имени Ермил Прокопьевич, или как перечень имён (знаков препинания в рукописи нет). Кроме того, морфологически слово ерлила аналогично слову курила, и нельзя исключать здесь и возможность глагольного осмысления.

Микротекст 2 представляет собой грамматически правильное предложение на русском языке СВЯТоГО СъН ПОД ЗАБоР УПаЛ.

При первом приближении микротекст 2 действительно выглядит как вырванная из контекста «цитата» русского текста (прототекста). Однако достаточно в самых общих чертах знать заговорную традицию русских, чтобы увидеть явную чуже- 
родность этой «цитаты». Если образ «святого сына» ещё можно «вписать» в систему заговорных персонажей (при наличии соответствующих сакральным персонажам функций), то мотив «сакральный персонаж падает под забор» противоречит заговорной картине мира и в лучшем случае, может быть интерпретирован как пародия на традицию.

Ещё большую абсурдность такой реконструкции прототекста придаёт подобная же интерпретация лексического содержания микротекста 1. Если рассматривать (в одном ряду с ПРоКӦ ЕРМиЛА 'Ермил Прокопьевич' / 'Прокопий, Ермил') слово МуРА как некий антропоним или персоним, а слово КУРиЛА как русский глагол (соответственно, ограничив степень «заумности» синтаксическим уровнем: синтаксически правильная конструкщия словосочетаний, не имеющая связного смысла), то к мотиву «сакральный персонаж падает под забор» может быть присовокуплён мотив «персонаж Мура курила/окуривала некоего человека по имени Прокӧ Ермила / Прокопия, Ермила» или «персонаж Мура курила/окуривала; персонаж Прокӧ «ермила». Возникающий таким образом «сценарий» складывается в определённый «сюжетный» ряд, но, очевидно, дальнейшие разыскания в данном текстологическом русле не выведут к искомым протоисточникам.

Поэтому вернёмся на исходные позиции и посмотрим на этот заговор с позиций доминантного, то есть коми языка. Поскольку лексическое содержание явно этому противоречит, попробуем обратить внимание на конструктивные особенности текста и найти хотя бы самый обобщённый, концептуально возможный выход на тему «заговорная традиция коми». Обозначим ещё раз исходные пункты:

- перед нами заговорный текст, записанный от коми исполнителя и бытовавший в коми традиции;

- при всех недостатках фиксации магического акта сам заговорный текст записан полностью, и, по всей вероятности, в таком виде и бытовал в традиции;

- по своей лексико-синтаксической структуре текст ориентирован на русскоязычность и, с большой долей вероятности, восходит к русскоязычному прототексту (или прототекстам), однако его жанровая принадлежность нам неизвестна; 
- соответственно, перед нами текст с неопределённо выраженной семантикой, что предполагает поиск заложенных в нём смыслов на периферии нормативного языка.

Итак, исходим из того факта, что перед нами заговорный текст, бытовавший в коми традиции. Наблюдаемая в коми языке тенденция ставить ударение на первый слог слов сказалась и на старых заимствованиях из русского языка, к которым в данном случае можно отнести слова КуРИТНЫ 'курить', СЬВаТӦЙ 'святой' (хотя здесь мы можем исходить и из церковнославянского СВяТЫЙ). Принимая первую строку заговора за «шаблон» (она задаёт определённый слого-ритмический размер), можно попытаться реконструировать просодический «облик» - или в терминах ритмики - «лексический ритм» ${ }^{4}$ этого заговора. Оговоримся, что здесь мы не затрагиваем звуковысотную специфику ударения: в коми-зырянском языке ударение музыкальное, отличное от выдыхательно-долготного в русском, и знак "v", по сути, обозначает не столько ударение, сколько повышение тона.

В результате такой реконструкции перед нами возникает почти идеальный двустопный дактиль с пиррихием, отмечающим концы строк:

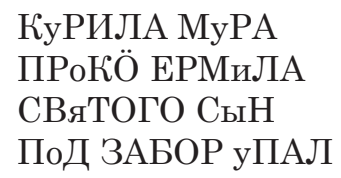

$$
\begin{array}{ll}
\mathbf{v}-- & \mathbf{v}- \\
\mathbf{v}-- & \mathbf{v}- \\
\mathbf{v}-- & \mathbf{v} \\
\mathbf{v}-- & \mathbf{v}-
\end{array}
$$

Помимо единственной неточности метра в третьей строке (выпадение безударного слога), мы имеем одно морфологическое несоответствие русскому языку (если исходить из тезиса о наличии русскоязычного прототекста), которое может быть объяснено так.

ПоД-ЗАБОР - допустимая в русской речи клитика (предлог сливается с последующим словом); формально мотивированный перенос ударения уПАЛ (< УПаЛ) соответствует ритмической структуре. Здесь стоит обратить внимание на орфографическую «заминку», возникшую у собирателя: первоначально предлог под был написан в одну строку с предыдущим святого сын, а затем вычеркнут. Это подтверждает наше предположение о наличии здесь просодического «сдвига», что и могло вызвать ошибку в слуховом восприятии. 
Правомерность дальнейшей интерпретации в таком русле можно подкрепить тем, что реконструированная ритмическая структура уже позволяет видеть определённые соответствия вербального и акционального кодов. Если соотнести ритм с воспроизводимым во время заговаривания действием (вращательные движения пальцем в воде), логично предположить, что каждая стопа соответствует одному обороту пальца; при этом, вращение, соответственно, неравномерное, импульсное (ритм $3 / 4+2 / 4$ ) и совпадающее с ритмом заговаривания. (Вращательные движения «под дактиль», в свою очередь, вызывают ассоциацию с ритмом вальса, однако была ли актуальна эта ассоциации заговора с вальсом для носителя коми традиции в 1935 г., судить сложно. Но едва ли случаен тот фракт, что большинство традиционных танцев в ритме «три четверти» связаны с вращением. Так, например, сами названия предшественников современного вальса - немецкий «Waltzen» и итальянский «Volta» означают «вращаться».) Другими словами, именно такая ритмическая (метрико-ритмическая) структура заговора наиболее соответствует акциональному уровню.

Теперь обратимся к единственной неточности метра в третьей строке (выпадение безударного слога) и попытаемся интерпретировать её:

\section{СВяТОГО СыН v - - v}

Если мы попытаемся восстановить «чистый» метрический вид Микротекста 2, то наиболее возможный вариант будет таким:

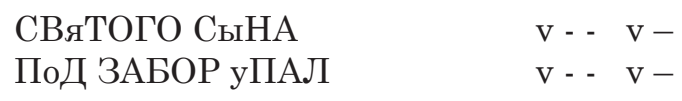

Будучи метрически правильным, этот вариант ошибочен с точки зрения русской грамматики, поскольку нарушено согласование по падежу. Поэтому можно допустить, что выпадение безударного слога есть результат правки микротекста 1 «под правильный русский». Эта правка вполне могла возникнуть позже, в ходе бытования заговора в традиции и, возможно, является результатом вмешательства уже другого языкового сознания, носитель которого в определённой степени владел русским языком. Не 
исключено также, что такая правка могла произойти и в сам момент фиксации заговора, поскольку для собирателя-студентки, а, возможно, и для исполнителя в 1935 г. подобная грамматическая неточность была очевидной и могла быть воспринята как речевая ошибка.

«Неправильное» словосочетание святого сына вызывает устойчивую ассоциацию с общеизвестной молитвенной формулой «Во имя отца, и сына и святого духа (Аминь)». В заговорно-заклинательной практике коми эта формула имела широкое распространение, могла применяться как самостоятельный нилкыв-заговор, так и в составе других вербальных текстов (некоторые из них мы рассмотрим ниже); кроме того, она была общеизвестна и из церковно-приходской практики. Однако заметим, что возникающая между образом «святого сына» и молитвенной формулой ассоциация нелинейна - то есть святой сын не является прямой цитатой из текста, а представляет собой некий концентрат, экспрессивно-смысловой срез формулы. Чтобы понять принцип такой концентрации (= преобразования), можно обратиться к методу позиционного анализа текста, основанного на идее «золотого сечения» как пропорции оптимальности (Москальчук 1998). Этой пропорции «золотого сечения» соответствует гарлонический иентр текста (далее - ГЦ), определяемый коэффрициентом 0,618 от размера целого. В качестве единиц счёта могут использоваться словоформы, синтагма, предложение, строка, страница, глава, которые рассматриваются как доли от единицы (целого текста). На обширном фрактическом материале доказано, что именно позиция ГЦ текста является кульминативной на смысловом, интонационном, ритмическом и других уровнях его организации (Черемисина 1981, 1989; Москальчук 1998, 2003; Корбут 2005).

\section{ВО иМЯ ОТЦа И СыНА И СВЯТоГО ДуХА (АМиНЬ) > СВяТОГО СЫНА}

Поскольку нас интересует только позиция ГЦ всего текста, процедура его вычисления достаточно проста: принимаем за целое 1 общее количество элементарных единиц текста и определяем точку пропорции 0,618 : 0,382. Исходя из того фракта, что 
мы имеем дело с заимствованием, можно принять в качестве элементарной единицы позиционного анализа фонетическое слово ${ }^{5}$ или слог как минимальный элемент слого-ритмической структуры (для текста такого объёма между ними не будет принципиальной разницы).

После несложных вычислений мы выясняем, что ГЦ этого 14 (16)-сложного (или 5 (6)-словного) текста (допуская возможность отсутствия слова алинь в формуле) оказывается между 8 и 9 слогами (или между 3 и 4 словами), т. е. или на втором слоге слова сыциа, или между сыцна и святого. Таким образом, мы можем предположить, что в результате трансформации (компрессии) этой молитвенной формулы (воспринимаемой языковым сознанием и, соответственно, синтагматически выделяемой в исходном прототексте заговора как отдельный микротекст) в конечном тексте сохранился компонент, соответствующий ГЦ формулы <сьна и святого>. Инверсия этого компонента <cына и святого $>\rightarrow$ святого сын (a) может быть связана с принципом телеологичности «сборки» текстовой конструкции заговора (от конца к началу).

Далее, если мы таким же образом проведём позиционный анализ всего рассматриваемого заговора, то увидим, что ГЦ всего текста (19-сложного или восьмисловного) совпадает с ГЦ молитвенной формулы и так же оказывается между словами святого и сьин. Более того, в этом месте сходятся ещё несколько уровней размерности текста: этот же ГЦ будет и на уровне метрики, и на уровне строфики:

$\begin{array}{ll}\text { КуРИЛА МуРА } & \mathbf{v}--\mathbf{v}- \\ \text { ПРоКӦ ЕРМиЛА } & \mathbf{v}--\mathbf{v}- \\ \text { СВяТОГО * СыН } & \mathbf{v}-{ }^{*} \mathbf{v} \\ \text { ПоД ЗАБОР уПАЛ } & \mathbf{v}--\mathbf{v}-\end{array}$

Таким образом, несмотря на смысловую (лексическую) бессвязность, рассматриваемый заговор достаточно жестко структурирован и гармонизирован. Находящийся в ГЦ заговора компонент святого сына является результатом нелинейного преобразования молитвенной формулы, входившей в состав русскоязычного прототекста. 
Если истоки появления персонима святой сыљ в данном заговоре более или менее правдоподобны, то мотив «падения под забор» на таком прототекстовом фоне выглядит ещё более абсурдным. Поэтому попытаемся и к этому мотиву подойти с тех же позиций нелинейности, т. е. не воспринимать его как фррагмент прототекста, а как вариант подобной же компрессии какой-то прототекстемы (заговорной фрормулы, паремии и т. п.).

Итак, у нас есть вполне надёжная точка отсчёта - наличие в прототексте молитвенной формулы. Ограничившись имеющимися в нашем распоряжении вариантами лечения сглаза, мы обратили внимание на ещё один заимствованный заговор от вомидз 'сглаза':

Спаса-Варука,

Причистая владьюка,

Железньй стын,

Медные ворота!

Отойдите от леня,

Отшатните от леня

Все нечистье дуки

Все видь и все болезни. Сал Кристос "благослови Криcmoc»

Во иля отиа... Алинь (Сидоров 1997: 163-164).

Вероятно, этот текст был переписан А. С. Сидоровым из рукописного текста в с. Лопыдино по р. Локчим (средняя Вычегда). Здесь, как мы видим, в качестве финальной закрепки используется та же формула "Во имя отца...», а сам заговор представляет собой набор типичных охранительных (оградительных) формул. Тем не менее, в нём явно видны следы специфического восприятия смысловой организации русскоязычного заговора, в соответствии с которым атрибутив Спасова рука трансрормировалась в двойной персоним (агионим) Спаса-Варука. Возможно, по ассоциации с именем Варук / Варука 'Варюха (Варвара)', дополняющим Причистую владыку.

Еще одной причиной для подобного переосмысления, видимо, послужило изменение ритмического строя заговора, при котором русское слово рука стало произноситься с ударением на первом слоге РуКА. Об этом, в частности говорит и появление варианта с множественным числом РуКИ: 
Христос во всел скӧт и двор, благодатнӧй дол, круглӧй во дворь, крепкой стын, железной стын, неотданнӧй ворота; от зелли до небеса спасовая руки, Пречистая залытти, Христос печать (Nalimov 1908: 1110).

Эта «молитва при затворе ворот» была записана в начале прошлого века В. П. Налимовым на нижней Сысоле. К сожалению, это тоже рукописная запись, и мы не берёмся точно воссоздать его ритмическую структуру. Однако, судя по последней формуле, концовка была такой: СПаСОВАЯ РуКИ, ПРЕЧиСТАЯ ЗаМЫТИ, ХРиСТОС ПеЧАТЬ. Для большей убедительности приведём ещё один вариант (по аудиозаписи) этой же формулы:

аСЛАД аНДЕЛЫД ВеСБКЫД, А НеЧИСТӦЙЫД ШуЙГА ПеЛЬПОМ ВыЛАД. ВеК ПӦ ТІ КуИМӦНӦСЬ, ШуЛЫВЛӦМАСЬ: "КРИСТОВА ПеЧА, ПаСОВЕЯ РУКА, ПРИЧИСТАЯ ЗаМОК, аНДЕЛЬСКЕЯ МОЛИТВА». Й Г НАЛАС и ТоМЛАЛАС ТэНӦ ЛёКСИС, аСЛАД аНДЕЛЫД. аСЛАД аНДЕЛЫД Пе СіЯ ВеК ТэНАД ПеЛЬПОМ ВыЛАД, ТәНЭС КРаНИТӦ̈

Свой ангел на правом, а нечистый на левом плече [сидят]. Всегда, мол, вы втроём, раньше сказывали. «Христова печать, Спасовея рука, Причистая залок, андельская молитва». Запрёт и замкнёт тебя от всего худого, свой ангел. Свой ангел, мол, всегда на твоём плече, хранит тебя.

Как видим, лексический ритм заговора здесь абсолютно соответствует просодической структуре всего текста.

Итак, обозначим важные для наших разысканий моменты:

- атрибутив Спасова рука в силу семантической неопределённости, непонятности для коми исполнителей обладает повышенной вариативностью.

- во всех рассмотренных вариантах РУКа преобразована в «хорей» (РуКА / РуКИ);

- кроме того, компонент СПаСОВА РуКа / СПаСА-ВАРуКа (СПаСОВАЯ РуКИ/ ПаСОВЕЯ РуКА представляет подходящую «заготовку» для двустопного дактиля с пиррихием, то есть для ритмической структуры нашего заговора. 
Отталкиваясь от этих пунктов, мы предлагаем такой вариант нелинейного преобразования:

\section{СПаСОВА РуКа}

\section{ПоД ЗАБОР уПАЛ}

Поскольку анализируемый заговор как особая речевая форма (вербально-магический регистр) мог характеризоваться интонационным и артикуляционным усилением, ряд фонетических изменений можно связать с особенностями этого вербально-магического регистра:

- в результате артикуляционного усиления щелевой /v/ превращается в фонетически похожий звонкий твёрдый согласный /b/: СПаСОВА > СПаСОБА;

- в результате артикуляционного усиления происходит озвончение /S/ > /Z/: CПаCOBA > СПаЗОБА; кроме того, озвончение согласных (интервокальных и в начале слова) вообще характерно для коми-зырянского языка. В качестве ещё одного варианта озвончения приведём инципит коми свадебного причитания «Пазда да Причистая» (< Спас да Причистая $)^{7}$;

- ассимиляция согласных: СПаСОВА РуКА > СПаСАВА РуПА;

- просодические сдвиги под воздействием этимологических ассоциаций СПаЗАБА РуПА > (С)Па ЗАБА-Р уПА(Л).

Вероятно, можно особо выделить ещё ряд закономерных фонетических изменений, однако и сказанного достаточно, чтобы представить общий порядок реконструкции:

CПаСОВА РуКА > СПаСАВА - РуПА > Па - САВАР - уПА(Л) $>$ Па - ЗАБАР уПА(Л $>$ \ Па(Д) ЗАБАР уПАЛ > ПоД ЗАБОР уПАЛ

Слово забор в значении 'забор, ограда' (< рус.), скорее всего, является поздним заимствованием советского времени, как, собственно, и сама традиция огораживать забором деревенские участки. Как и в русском языке, первичным значением этого заимствования могло быть 'загородка, перегородка (в избе)' (ССКЗД: 126). 
Кроме того здесь могло иметь место промежуточное звукосмысловое звено - заимствованное слово завор 'разборное прясло (часть изгороди)', 'ворота в изгороди для проезда' < рус. 'околица, забор, городьба, прясла' (КЭСКЯ: 104); оно зафиксировано во всех диалектах коми языка и, видимо, является достаточно ранним заимствованием, поэтому этимологизация асемантичного савор в завор (а уже далее в забор) вполне ожидаема.

В нашем распоряжении нет устойчивой формулы или микротекста с атрибутивом Спасова рука, поэтому мы не можем повторить позиционный анализ, аналогичный проведённому выше разбору компонента святого сын. Несомненно то, что в гипотетическом прототексте Спасова рука занимала сильную позищию, закреплённую ещё и слогоритмически $(\mathbf{v}--\mathbf{v}-)$.

\section{Предварительные выводы}

В результате предложенной реконструкции нам удалось выявить возможные истоки микротекста 2. Таким образом, прототекст анализируемого заговора уже обрёл определённое лексико-семантическое наполнение, характерное для заговорного текста. Формулы «Во имя отца...» и "Спасова рука...» присутствуют и в приведённых в качестве иллюстративного материала примерах, а заговор от сглаза-волидз с инципитом Cnaca-Bapyкa, в принципе, может быть принят как вариант искомого источника. Имея уже вполне конкретные представления о возможном содержании прототекста, обратимся к первой части.

\section{Микротекст 1}

КуРИЛА МуРА ПРоКӦ ЕРМиЛА

$$
\begin{array}{ll}
\mathbf{v}-\mathbf{v}- \\
\mathbf{v}-\mathbf{v}-
\end{array}
$$

Эта часть заговора имеет более глубокую степень семантической неопределённости, и, вероятно, морфологические соответствия (учитывая уже возникшие антропонимы ПРоКӦ 'Прокопий' < ?; ЕРМиЛА 'Ермил' < ? (или 'Ермил Прокопьевич') - это результат спонтанных этимологических аттракций. И любые попытки 
отыскать в них следы прототекста (? < впрок / проговорила / и т. п.) будут выглядеть крайне неубедительно. Поэтому выберем другую тактику и попытаемся глубже проникнуть в формальную организащию этого микротекста.

Две первые строки заговора идентичны по метрике (двустопный дактиль с пиррихием), однако при этом по ряду параметров противопоставлены друг другу. Прежде всего можно отметить явную морфологическую (а если рассматривать слово ерлила как глагол с неопределённой семантикой, то и синтаксическую) зеркальность двух строк: трехсложный «глагол» + двусложное «существительное» // двусложное «существительное» + трёхсложное «существительное/квазиглагол». Этот принцип зеркальной симметрии можно увидеть и на фоноритмическом уровне:

\section{Зеркальная симметрия}

$\begin{array}{lll}\text { КуРИЛА МуРА } & :: & \text { ПРоКӦ ЕРМиЛА } \\ 3+2 & :: & 2+3 \\ \text { КР - МР } & :: & \text { РК }- \text { РМ } \\ \text { РИЛА }- \text { М-Р } & :: & \text { ПР }- \text { РМИЛА }\end{array}$

Как видим, микротексту 1 присуща вполне чёткая зеркальная структура, поэтому совершенно логично предположить, что на неё накладывается ещё и звукоизобразительный план. Фоносемантический анализ в его современной интерпретации достоин отдельного исследования (см. Михалёв 2009), и чтобы не увязнуть в этой теме, обратимся к уже имеющимся наработкам в этой области. Поскольку звукоряд Микротекста 1 так или иначе соотнесён с общей звуко-ритмической структурой текста, отберём наиболее частотные для всего заговора звуки и соотнесём их с данными об универсальных фоносемантических типах (Михалёв 1995: 86 и след.). Частотный срез будет таким: гласные фонемы [U] - 3 ударных, [O] - 2 ударных + 4 безударных; согласные: [B/P] - 4; [R] - 5; [L] - 3; созвучия: [RL-ML-PL], [KR-MR-PR-JR-BR], [RLMR], [JRML]; 


\section{Таблица потенциальных значений фонем}

\begin{tabular}{|l|l|l|l|}
\hline dронемы & $\begin{array}{l}\text { звукоподра- } \\
\text { жательные } \\
\text { значения }\end{array}$ & $\begin{array}{l}\text { артикуляционно- } \\
\text { символические } \\
\text { значения }\end{array}$ & $\begin{array}{l}\text { синестетическое } \\
\text { развитие }\end{array}$ \\
\hline$[\mathrm{O} / \mathrm{U}]$ & $\begin{array}{l}\text { завывающие } \\
\text { звуки }\end{array}$ & $\begin{array}{l}\text { «округлый», } \\
\text { «глубокий» }\end{array}$ & $\begin{array}{l}\text { «тяжёлый», } \\
\text { «тёмный» }\end{array}$ \\
\hline$[\mathrm{B} / \mathrm{P}]$ & $\begin{array}{l}\text { взрывные, } \\
\text { бьющие, буль- } \\
\text { кающие звуки }\end{array}$ & $\begin{array}{l}\text { «удар», } \\
\text { «объёмное», } \\
\text { «раздутое» }\end{array}$ & $\begin{array}{l}\text { «круглое», } \\
\text { «полное», } \\
\text { «большое» }\end{array}$ \\
\hline$[\mathrm{R}]$ & $\begin{array}{l}\text { длительные } \\
\text { дрожащие } \\
\text { шумы }\end{array}$ & $\begin{array}{l}\text { «круговое } \\
\text { вращение», } \\
\text { «повторяемость», } \\
\text { «напряжённость» }\end{array}$ & $\begin{array}{l}\text { «круглый», } \\
\text { «дижение } \\
\text { вообще» }\end{array}$ \\
\hline$[\mathrm{L}]$ & $\begin{array}{l}\text { длительные } \\
\text { дрожащие } \\
\text { шумы }\end{array}$ & $\begin{array}{l}\text { «лакание», } \\
\text { «лизание», } \\
\text { «жидкость» }\end{array}$ & «льющийся» \\
\hline
\end{tabular}

Фонемы [U], [О] (в нашем тексте встречаются 9 раз, из них пять ударные): лабиальные - «округлость»; заднего ряда, далеко (глубоко) от выхода звука - «глубокий». Понятия «тяжёлый» и «тёмный» - следствие синестезии с «глубоким».

Лабиальные взрывные [B/P] (встречаются четыре раза): лабиальность указывает на понятие «округлости» (особенно в сочетании с лабиальными гласными); взрывной характер согласных прекрасно передаёт звукоподражательное значение «взрыв», а сильное отталкивание губ друг от друга изображает «удар»; разновидностью взрыва может представляться «бульканье», или "кипение», в то время как раздувание щёк перед выбросом воздуха способно символизировать нечто «объёмное, раздутое». Заметим, что эти звукоизобразительные параметры также могли «спровоцировать» реконструированный выше переход РуКА > РуПА и далее уПАЛ.

Вибрант [R] (встречается пять раз): чрезвычайно широкие звукоподражательные возможности в изображении длительных дрожащих шумов («континуантов»); колебательные движения языка изображают различные виды «дрожания, колебания»; 
одна из основных черт процесса колебания - многократное возвращение в первоначальное положение, т. е. «повторяемость, возвращение назад», что явилось одной из символических фрункций $[R]$; с другой стороны, дрожание очень напоминает катание языка по нёбу - отсюда возможность обозначать через него "вращательное, круговое движение» и далее «круглое» и «движение вообще»; энергичная артикуляция звука со свойством «напряжённость».

Латеральный сонант [L] (встречается три раза): связывается с «жидкостью» на основании характерного жеста языка как органа лизания и лакания; в свою очередь, «жидкость» создаёт возможность символизирования по таким свойствам, как «льющийся», «плавный, ровный, гладкий», «липкий», «скользкий», «лёгкий» и т. п.

Таким образом, выделенные фроносемантические характеристики могут быть объединены в общий звукосимволический образ "круговое движение, вращение жидкости». А этот образ весьма точно соответствует и акциональному уровню, и метрико-ритмической структуре заговора в целом.

\section{Гипотеза порождения заговорного текста}

Заговорный текст имеет жёстко формализованную ритмическую структуру. Количественные и качественные параметры этой структуры определены тем, что она обладает гармоническим центром и соответствующими этому ГЦ границами. Поэтому правомерно говорить не о структуре, а о наличии особой ритмической матрицы. Именно эта матрица воспроизводится на разных уровнях организации словесного текста (звукоритмическом, слогоритмическом, метрико-ритмическом и т. д.) и на акциональном уровне заговорного акта.

Реконструированные нами компоненты заговорного прототекста демонстрируют нелинейный характер его трансформации в конечный текст. Часть заговора (Микротекст 2) представляет собой лексико-синтаксически верифицированную как "русскоязычное предложение» комбинацию компонентов фрормул «Во имя отца и сына и святого духа» и «Спасова рука». Вторая часть заговора представляет собой микротекст с деформированной 
лексико-семантической структурой (морфологическую заумь), также верифицируемый как русскоязычный. Выявить исходные компоненты первоисточника не представляется возможным. В общей ритмической матрице эта часть согласована по всем рассмотренным уровням, кроме лексико-синтаксического. На фоносемантическом уровне две части заговора объединены общими звукосимволическими значениями, обобщёнными нами в образ «круговое движение, вращение жидкости»; этот образ соответствует акциональному уровню магического обряда и ритмической матрице в целом.

Отсутствие смысловой связности при столь жёсткой формальной организации текста позволяет уверенно говорить о том, что между источником заимствования (прототекстом) и конечным результатом в принципе не могло быть промежуточных вариантов. При любом отклонении от матрицы текст потерял бы связность и целостность и распался. Поэтому речь здесь должна идти об одношаговой, одномоментной трансформации прототекста в текст. В пользу такой гипотезы говорит ещё один важный параметр - это объём заговорного текста (8 слов), соответствующий объёму разового восприятия текста (см. подробнее Рабинович 2010). $7 \pm 2$ объекта - это объём разового восприятия сознания, ширина информационного коридора или средний объём кратковременной памяти взрослого человека (кратковременной называют память, способную сохранять информацию в течение 25-30 секунд после прекращения процесса её восприятия). В лингвистике этот объём называется числом Ирвин-Миллера и определяет максимальное количество слов в устном предложении, позволяющее речи быть понятной: когда мы воспринимаем чью-то речь на слух, нам приходится выкладывать в голове все слова в единое целое, чтобы получился смысл. Поле этой выкладки ограничено 5-9 элементами. И только потом мозг переходит к пониманию следующего предложения.

Говоря об одноразовом действии, наиболее вероятно здесь представить коммуникативную ситуацию «учитель - ученик»: учитель воспроизводит заговорно-заклинательный акт с прототекстом, а ученик в силу определённых установок воспринимает не сам заговорный текст, а более глубинные уровни магикоритуального перформатива. Эти уровни со всей очевидностью связаны с реконструированной нами ритмической матрицей. 
Какие-то параметры этой матрицы в силу недоступности нами не учтены (ритмомелодика речи, особенности звукоизвлечения, включённость предметно-изобразительного ряда и т. п.). Для достижения коммуникативной цели ученик, вероятно, должен уметь входить (или вводится учителем) в определённое психофризиологическое состояние (изменённое состояние сознания, возможно, психотехнически обусловленное), активизирующее когнитивные процессы в ситуации цейтнота. Ученик вначале воспринимает ритм заговаривания, синхронизирующий речь и действия учителя; далее в его сознании «собирается» ритмическая матрица, в которую «встраивается» вербальный ряд, собранный из компонентов текста-источника, "выхваченных" кратковременной памятью обучаемого. Вероятно, произносимый учителем заговорный текст воспринимается как динамическое смысловое целое, из которого выделяются гармонические или резонирующие соответствия матрице. Так, в ГЦ матрицы «вставляется» компонент, занимающий ГЦ молитвенной формулы «Во имя отца...»; вероятно, определённый «резонирующий» признак (помимо метрико-ритмического соответствия) был присущ и формуле Спасова рука. Можно предположить, что словесный текст конструируется «снизу вверх», то есть от звуко-ритмических ассоциаций к слого-ритмическим, морфемо-ритмическим (из слого-ритмических ассоциаций собираются морфологические подобия), лексико-ритмическим (из морфологических соответствий собираются лексические подобия), и далее лексико-синтаксическим. Первая часть текста «застывает» на предпоследнем уровне, превращаясь в мордологическую заумь. То есть опять же «заумность» - это результат компрессии словесного материала в ритмическую структуру, и в идеале, новый текст мог бы полностью соответствовать доминантным нормам связности и цельности.

Очевидно, что такой, «нелинейный» способ перенимания заговора не согласуется с общераспространёнными представлениями о прямом обучении вербальным знаниям и может быть интерпретирован как особый, эзотерический вариант посвящения. Не случайно среди популярных в фольклоре коми представлений о передаче магических знаний встречаются типологически близкие, «когнитивные» версии, например: 
Нилкыв-заговор передают, только последнее слово не договаривают. И так каждый раз, всё короче и короче. Не знаю, наверно, салолу нужно это слово найти. (Этноградия детства 1999: 60)

Кроме того, наша гипотеза согласуется с рассмотренными С. Б. Адоньевой фрактами существования надвербального, стратегического уровня заговорного знания: «Компетентность проявляется не в знании ритуальных текстов, но в свободном владении различными магическими стратегиями, владении, дающем возможность порождать магические высказывания самостоятельно, за счёт подключения дополнительных кодов, меняющих форму знаков, используемых для магических актов» (Адоньева 2004: 123). А рассмотренный нами коммуникативный акт фоксирует рождение нового вербально-магического регистра, нового заговора-нилккыв, в силу начальных условий «посвящения» соответствующего психофизиологическим параметрам посвящаемого и, вероятно, его биоэнергетике.

\section{Сокращения}

НМ РК - Национальный музей Республики Коми

ФФ ИЯЛИ - Фольклорный фонд Института языка, литературы и истории Коми Научного центра УрО РАН

\section{Примечания}

1 Зап. М. М. Прокушева в 1935 г. в Усть-Куломском р-не Республики Коми. Исполнитель не зафиксирован. (НМ РК: КП-12481. Фольклор коми учащихся педтехникума. 1932-1935 гг. Л. 491).

2 В силу ограниченности объёма статьи мы опускаем обсуждение проблем, связанных с суггестивными свойствами ритма, и отметим наиболее близкие к нашей теме работы: о взаимосвязи заговорного ритма и ритмомелодики с психотерапевтическим, энергоинформационным, биоэнергетическим планами магического воздействия: (Харитонова 1995, 1999); о ритмической структуре суггестивных текстов (Черепанова 1996; Болтаева 2003; Пищальникова \& Чернова 2003); 
о ритмической организации заговорных текстов (Хворостьянова 2004: 88-107; Толстая 2005: 292-308).

3 Зап. Софья Попова в июне 1935 г. Без паспортных данных. (НМ РК: КП-12481. Фольклор коми учащихся педтехникума. 1932-1935 гг. Л. 143).

${ }_{4}$ В связи с ударением принято говорить о ритмической структуре слова, которая проявляется в тексте как особый уровень его ритмомелодики: «Лексический» ритм можно считать своего рода просодическим фундаментом, над которым "надстраиваются» ритмы более высоких уровней, связанные с синтагмами и предложениями» (Касевич \& Ягунова 2003: 19).

5 Фонетическое слово отличается от слова лексикографического или лексико-грамматического возможностью включать в свой состав, наряду с одним (в русском языке) знаменательным словом, одно, реже несколько, служебных слов-клитик. В языковом сознании носителей коми языка членение русскоязычного текста на фонетические слова может быть несколько иным. Например, вариант молитвенной dормулы, записанный Тойво Е. Уотилой от верхневычегодского комизырянина Михаила Жикина: Госпоги полилуй слава отсуйу сыьнуйу сьватама дуку ининейу приснэйу вовеки веком, аминь. (Syrjänische Texte 2006: 16).

6 Записано в с. Большелуг Корткеросского р-на Республики Коми от Ульяны Михайловны, 82 г. (фамилия не отмечена). Собиратель не зафиксирован (ФФ ИЯЛИ: А1117-3).

7 Зап. Е. Е. Осипова в 1935 г. от В. П. Ларуковой, уроженки с. Нившера Корткеросского р-на Республики Коми. Рукопись. (НМ РК: КП-12480. Фольклор коми учащихся педтехникума. 1930-1936 гг. Л. 37об.)

\section{Литература}

Адоньева, Светлана 2004. Прагматика фбольклора. Санкт-Петербург: Издательство Санкт-Петербургского университета.

Андреев, Даниил 2000. Некоторые заметки по стиховедению. - Даниил Андреев в культуре ХХ века. Москва, 236-259.

Болонев, Фирс \& Мельников, Михаил 1997. Русские заговоры Сибири и Дальнего Востока. - Русский календарно-обрядовый фбольклор Сибири и Дальнего Востока: Песни. Заговоры. Новосибирск, 245-272. 
Болтаева, Светлана 2003. Ритмическая организация суггестивного текста. Автореферат диссертации на соискание учёной степени кандидата филологических наук. Екатеринбург.

ВВД = Сорвачёва, Валентина \& Сахарова, Марфа \& Гуляев, Евгений 1966. Верхневычегодский диалект коли языка. Сыктывкар: Коми книжное издательство.

Виноградова, Людмила 2002. Та вода, которая... (Признаки, определяющие магические свойства воды). - Толстая, Светлана (ред.). Признаковое пространство культуры. Москва: Индрик, 32-60.

Давыдов, Данила 2007. К проблеме семантизации текстуального статуса: из заметок о поэтической зауми. - Андреева, Н. Н. \& Литвиненко, Н. А. \& Пахсарьян , Н. Т. (ред.). Литература XX века: итоги и перспективы изучения. Материаль Плтых Андреевских чтений. Москва, 66-72; http://natapa.org/wp-content/uploads/2011/03/ davydov.pdf (дата обращения 01.12.2014).

Завьялова, Мария 2006. Балто-славянский заговорный текст: Лингвистический анализ и модель мира. Москва.

Касевич, Вадим \& Ягунова, Елена 2003. Ударение и фонетическое слово в русском языке. - Ерофеева, Т. И. (отв. ред.). Проблелиы соиио- и психолингвистики. Вып. 3. Пермь: Пермский университет, 19-25; http://psychsocling.narod.ru/kasevich_jagunova.htm.

Кляус, Владимир 2004. О некоторых влияниях русской заговорной традиции на бытование заговорно-заклинательного фольклора удмуртов. - Народные культуры Русского Севера. Фольклорный энтитет этноса. Вып. 2: Материалы российско-финского симпозиума (Архангельск, 20-22 ноября 2003). Архангельск, 200-203.

Корбут, Александра 2005. Текстосимлетрика как раздел общей теории текста. Автореферат диссертации на соискание учёной степени доктора филологических наук. Барнаул.

КЭСКЯ = Лыткин, Василий \& Гуляев, Евгений 1999. Краткий этимологический словарь коми языка. Переиздание с доп. Сыктывкар.

Левкиевская, Елена 1999. Заумь как разновидность ритуальной речи славян. - Толстой, Никита (ред.). Славянские древности: Этнолингвистический словарь. Т. 2. Москва, 279-282. 
Манаков, Николай \& Москальчук, Галина 1999. Текст как природный объект. - Педагог: Наука, технология, практика. № 2 (7). Барнаул: Издательство Алтайского университета, 58-62.

Михалёв, Андрей 1995. Теория ббоносемантического поля. Пятигорск: Издательство ПГЛУ.

Михалёв, Андрей 2009. Современное состояние фоносемантики. Новые идеи в лингвистике XXI века. Материалы 1 Международной научной конференции, посвящённой памяти профессора В. А. Хомякова. Ч. 1. Пятигорск, 52-59.

Москальчук, Галина 1998. Динамика формы текста. - Языковая картина мира: лингвистический и культурологический аспекты. Т. 2. Бийск, 22-26.

Москальчук, Галина 2003. Структура текста как синергетический процесс. Москва: Editorial URSS.

Никонова, Людмила 2000. От Адама и Евъь - до наших дней: (Очерки народной медицины мордвы). Саранск.

Панина, Татьяна 2014. Слово и ритуал в народной медицине удлуртов. Ижевск: УИИИЯЛ УрО РАН.

Панюков, Анатолий 2009. Динамика развития коли фбольклорных традиций в контексте теории самоорганизации. Сыктывкар: Институт языка, литературы и истории Коми НЦ УрО Российской академии наук.

Панюков, Анатолий 2010. К вопросу о самоорганизации зауми (на материале коми считалок). - Вестник Челябинского государственного университета. № 34 (215). Филология. Искусствоведение. Вып. 49, 93-98.

Панюков, Анатолий 2014. Из детской промысловой магии комизырян. - Традищионная культура. № 3 (55). Москва, 46-157.

Пищальникова, Вера \& Чернова, Мария 2003. Ритмолелодическая структура текста как репрезентант элоционально-смысловой доминанты.. Москва-Горно-Алтайск.

Рабинович, Михаил 2010. Оперативная память и число семь. - Наука ижизнь 8; http://www.nkj.ru/archive/articles/18456/ (дата обращения 01.11.14). 
Самошкин, Анатолий 1975. О русско-мордовских фольклорных связях в заклинательной поэзии. - Вопросы фбинно-угроведения 6. Саранск, 332-338.

Сидоров, Алексей 1997. Знахарство, колдовство и порча у народа коми. Материаль по психологии колдовства. Санкт-Петербург: Алетейя. Переиздание книги 1928 г.

ССКЗД = Жилина, Татьяна \& Сахарова, Марфа \& Сорвачёва, Валентина (сост.) 1961. Сравнительныци словарь коми-зырянских диалектов. Сыктывкар: Коми книжное издательство.

Толстая, Светлана 2005. Ритм и инерция в структуре заговорного текста. - Заговорный текст. Генезис и структура. Москва: Индрик, 292-308.

Топорков, Андрей 2008. Магические тексты в устных и рукописных традициях России XVII-XVIII вв. - Одиссей. Человек в истории. Script/Oralia: взаимодействие устной и письленной традииий в Средние века и раннее Новое время. Москва, 13-28; http://www. rastko.rs/projekti/etnoling/delo/12026 (дата обращения 01.12.2014).

Топоров, Владимир 1993. Об индоевропейской заговорной традиции. Исследования в области балто-славянской духовной культурь: Заговор. Москва: Наука, 3-4.

Уляшев, Олег 1999. Нимкыв. - Мифология коли: Энииклопедия уральских мифбологий. Т. І. Москва-Сыктывкар: ДИК, 256-258.

Харитонова, Валентина 1995. Традииионная магико-медицинская практика и современное народное иелительство: статьи и материальь. Москва.

Харитонова, Валентина 1999. Заговорно-заклинательное искусство восточных славян: проблемы традиционных интерпретаций и возможности новых исследований. (Этнологические исследования по шаманству и иным традиционным верованиям и практикам. Т. 3, в 2-х частях). Москва: ИЭА РАН.

Хворостьянова, Елена 2004. Ритмический строй севернорусских заговоров. - Русский фбольклор XXXI. Санкт-Петербург: Наука, 88-107.

Черемисина, Нинель 1981. Вопросы эстетики русской художественной речи. Киев. 
Черемисина, Нинель 1989. Русская интонация: поэзия, проза, разговорная речь. Москва.

Черепанова, Ирина 1996. Дом колдуньи. Язык творческого Бессознательного. Москва: КСП.

Шляхова, Светлана 2006. Фоносемантические маргиналии в русской речи. Автореферат диссертации на соискание ученой степени доктора филологических наук. Пермь.

Этнография детства $1999=$ Панюков, Анатолий \& Савельева, Галина (сост.). Традииионная культура коми: Этнография детства. Материалы фольклорно-этнографических экспедиций 1995-1998 гг. Сыктывкар.

Janecek, Gerald 1996. Zaum: The Transrational Poetry of Russian Futurism. San Diego: San Diego State University Press.

Nalimov, Vasilij 1908. Kansatieteellisiä kirjoituksia ja muistiinpanoja syrjääneistä. Venäjäksi. Suomalais-Ugrilainen Seura Arkisto. I. 39. Helsinki.

Syrjänische Texte 2006. Gesammelt von Uotila, Toivo \& Kokkonen, Paula. Bd. 5. Helsinki. 


\section{ФОЛЬКЛОРИСТИКА КОМИ: исследования и материалы}

\section{http://www.folklore.ee/rl/pubte/ee/sator/sator17/}

ISSN 1736-0323

ISBN 978-9949-586-24-0

DOI: $10.7592 /$ Sator.2016.17

Тарту 2016

Авторы: Ирина Ильина, Юлия Крашенинникова, Павел Лимеров, Людмила Лобанова, Светлана Низовцева, Алексей Рассыхаев, Анатолий Панюков, Галина Савельева,

Олег Уляшев

Редактор серии: Маре Кыйва

Редакторы-составители выпуска: Людмила Лобанова \& Николай Кузнецов

Оформление обложки: Анатолий Панюков \& Андрес Куперьянов

Верстка \& HTML: Диана Кахре

Печатное издание: ФОЛЬКЛОРИСТИКА КОМИ: исследования и материалы. SATOR 17. Тарту 2016

Составление, техническое оформление и печать книги осуществлены при поддержке Эстонского институционального исследовательского гранта 22-5 (Религиозные и нарративные аспекты фольклора).

Оформление электронного издания осуществлено при поддержке проекта ЕККМ14-344 “Расширение областей применения и представление эстонского языка, культуры и фольклора в электронных информационных средствах".

(с) EKM Teaduskirjastus / Научное издательство ЭЛМ

(c) Авторы

(с) Анатолий Панюков \& Андрес Куперьянов 